\title{
RANCANG BANGUN KAMUS KEBIDANAN BERBASIS ANDROID DENGAN ECLIPSE
}

\author{
MOH. JASRI ${ }^{1)}$, AHMAD BUHARI ${ }^{2)}$ \\ 1) Jurusan Teknik Informatika STT Nurul Jadid Paiton Probolinggo \\ 2) Jurusan Teknik Informatika STT Nurul Jadid Paiton Probolinggo \\ e-mail: jasriahyak@gmail.com ${ }^{1)}$,ahmadbuhari11012099@gmail.com ${ }^{2)}$
}

\begin{abstract}
Kamus merupakan alat bantu yang digunakan untuk mencari arti kosakata suatu bahasa. Penggunaan kamus kebidanan yang berbentuk buku sangat menyulitkan pengguna karena memiliki ketebalan dan bobot yang cukup berat. Disamping itu kamus yang berbentuk buku mudah rusak dan kosa kata yang ada pada buku tidak dapat diperbaharui dengan kemajuan ilmu yang ada pada saat ini. Dengan kemajuan teknologi yang ada pada saat ini permasalahan tersebut dapat diatasi dengan membangun sebuah aplikasi kamus kebidanan yang berbasis android yang dapat digunakan sebagai media alternatif untuk mencari arti suatu bahasa. Pembuatan aplikasi ini menggunakan metode waterfall. Hasil dari penelitian ini menghasilkan aplikasi kamus kebidanan sebagai pengganti buku yang dapat membantu pengguna dalam mencari arti kosakata suatu bahasa. Sehingga proses pencarian arti kosakata suatu bahasa dapat lebih mudah dilakukan hanya dengan memasang perangkat mobile berbasis android.
\end{abstract}

Kata Kunci: Kamus, kebidanan, Android

\begin{abstract}
Dictionary is a tool that is used to search for the meaning of the vocabulary of a language. The use of book-shaped dictionary obstetric very difficult for users because it has a thickness and a fairly heavy weight. Besides, the book-shaped dictionary perishable and vocabulary of this book can not be updated with the progress of science that existed at this time. With the technological advances that exist at the present time these problems can be solved by building a dictionary application android based midwifery that can be used as an alternative media to find meaning in a language. Making these applications using waterfall method. The results of this study resulted in a dictionary application midwifery as a substitute for books that can assist users in finding the meaning of the vocabulary of a language. So that the process of finding the meaning of the language vocabulary can be easily performed by simply plugging the mobile devices based on Android.
\end{abstract}

Keywords: Dictionary, obstetrics, Android

\section{PENDAHULUAN}

Perkembangan teknologi komunikasi khususnya teknologi komunikasi seluler telah menciptakan fungsi baru selain fungsi utamanya sebagai sebuah alat komunikasi. Selain itu sistem operasi pada handphone pun sudah mulai berkembang, diantaranya sistem operasi android. Sistem operasi android memiliki keunggulan diantara sistem operasi lain karena sistem operasinya dapat diubah sesuai dengan keinginan kita sendiri. Kebutuhan masyarakat terhadap layanan IT sangat bervariatif, salah satu kebutuhan adalah kebutuhan akan ketersediaan kamus bahasa hingga kamus istilah-istilah khusus seperti kamus politik, kamus kedokteran, kamus istilah kebidanan dan sebagainya. Kamus kebidanan merupakan salah satu kamus yang diperlukan oleh mahasiswa kebidanan. Banyak sekali buku kamus istilah kebidanan yang beredar tetapi buku tersebut justru menyulitkan karena pengguna harus mencari arti dan istilah kebidanan secara manual,di sisi lain buku sangat sulit untuk di bawa dan membuka perlembar dari kamus istilah kebidanan, memakan waktu yang cukup lama dan kamus secara manual tidak dapat di update sesuai perkembangan ilmu kebidanan yang pada saat ini.

Salah satu teknologi yang bisa dijangkau oleh masyarakat luas adalah telepon seluler, semua orang bisa menggunakannya denga mudah, apalagi dengan harga yang sangat terjangkau hampir semua lapisan masyarakat memiliki dan juga mengenal telepon seluler[1].

Dengan kemajuan teknologi yang sangat pesat ini dibutuhkan adanya sebuah aplikasi yang dapat memudahkan orang dalam mencari dan memahami arti kata dan istilah kebidanan. Kamus tersebut haruslah dapat dengan mudah dipergunakan userfriendly oleh para pengguna komputer untuk menggunakan aplikasi ini serta dapat mengakomodir kebutuhan setiap pengguna akan sebuah aplikasi pengganti buku yang mudah dibawa serta dapat digunakan kapanpun dan dimanapun dengan efektif. 
Penulis bermaksud untuk memanfaatkan teknologi telepon seluler atau hp, untuk membuat kamus digital tentang kebidanan untuk memudahkan konsumen dalam pencarian kosakata tentang kebidanan.

\section{DASAR TEORI}

\subsection{Kamus}

Menurut kamus besar bahasa Indonesia, pengertian dari kamus adalah buku acuan yang memuat kata dan ungkapan yang biasanya disusun menurut abjad berikut keterangan tentang maknanya, pemakaiannya dan terjemahannya. Kamus dapat juga digunakan sebagai buku rujukan yang menerangkan makna kata-kata yang berfungsi untuk membantu seseorang mengenal perkataan baru. Selain menerangkan maksud kata, kamus juga mungkin mempunyai pedoman sebutan, asalusul (etimologi) sesuatu perkataan dan juga contoh penggunaan bagi sesuatu perkataan. Untuk memperjelas kadang kala terdapat juga ilustrasi di dalam kamus Terdapat banyak kamus yang populer di Indonesia, seperti : kamus bahasa Inggris, bahasa Jerman, bahasa Mandarin, bahasa Jepang dan lain sebagainya[2].

\subsection{Bidan}

Bidan seorang perempuan yang lulus dari pendidikan yang diakui pemerintah dan organisasi profesi diwilayah Negara Republik Indonesia serta memiliki kompetensi dan kualifikasi untuk diregister, sertifikasi dan atau secara sah mendapat lisensi untuk menjalankan praktik kebidanan. Bidan diakui sebagai tenaga professional yang bertanggung-jawabdan akuntabel, yang bekerja sebagai mitra perempuan untuk memberikan dukungan,asuhan dan nasehat selama masa hamil, masa persalinan dan masa nifas, memimpin persalinan atas tanggung jawab sendiri dan memberikan asuhan kepada bayi baru lahir, dan bayi. Asuhan ini mencakup upaya pencegahan, promosi persalinan normal, deteksi komplikasi pada ibu dan anak, dan akses bantuan medis atau bantuan lain yang sesuai, serta melaksanakan tindakan kegawat-daruratan. Bidan adalah seorang perempuan yang lulus dari pendidikan bidan yang telah teregistrasi sesuai ketentuan peraturan perundang-undang[3].

\subsection{Android}

Android adalah sebuah sistem operasi pada handphone yang bersifat terbuka dan berbasis pada sistem operasi Linux. Android bisa digunakan oleh setiap orang yang ingin menggunakannya pada perangkat mereka.
Android menyediakan platform terbuka bagi para pengembang untuk menciptakan aplikasi mereka sendiri yang akan digunakan untuk bermacam peranti bergerak. Awalnya, Google Inc. membeli Android Inc., pendatang baru yang membuat peranti lunak untuk ponsel. Kemudian untuk mengembangkan Android, dibentuklah Open Handset Alliance, konsorsium dari 34 perusahaan peranti keras, peranti lunak, dan telekomunikasi, termasuk Google, HTC, Intel, Motorola, Qualcomm, TMobile, dan Nvidia. Pada saat perilisan perdana Android, 5 November 2007, Android bersama Open Handset Alliance menyatakan mendukung pengembangan standar terbuka pada perangkat seluler. Di lain pihak, Google merilis kode-kode Android di bawah lisensi Apache, sebuah lisensi perangkat lunak dan standar terbuka perangkat seluler[4].

\subsection{Eclipse}

Eclipse adalah sebuah IDE (Integrated Development Environment) untuk mengembangkan perangkat lunak dan dapat dijalankan di semua platform (platformindependent). Eclipse pada saat ini merupakan salah satu IDE favorit dikarenakan gratis dan open source, yang berarti setiap orang boleh melihat kode pemrograman perangkat lunak ini. Selain itu, kelebihan dari Eclipse yang membuatnya populer adalah kemampuannya untuk dapat dikembangkan oleh pengguna dengan komponen yang dinamakan plug-in. Eclipse dibuat dari kerja sama antara perusahaan-perusahaan anggota 'Eclipse Foundation' (beserta individu-individu lain). Banyak nama besar yang ikut dalam 'Eclipse Foundation', termasuk IBM, BEA, Intel, Nokia, Borland. Eclipse bersaing langsung dengan Netbeans IDE. Plugin tambahan pada Eclipse jauh lebih banyak dan bervariasi dibandingkan IDE lainnya[4].

\subsection{Searching}

Searching adalah mekanisme pemecahan masalah yang paling umum di dalam kecerdasan buatan. Di dalam permasalahn-permasalahan kecerdasan buatan, urutan langkah-langkah yang dibutuhkan untuk memperoleh solusi merupakan suatu isu penting untuk diformulasikan. Hal ini harus dilakukan dengan mengidentifikasikan proses try and error secara sistematis pada eksplorasi setiap alternatif jalur yang ada.Metode searching pada kecerdasan buatan merupakan searching terhadap problem space, bukan pada data tertentu. Proses searching berupa jalur yang mengambarkan keadaaan awal sebuah masalah menuju penyelesaian. Proses searching menuju 


\section{SYSTEMIC}

Vol. 02, No. 01, Agustus 2016, 39-44

penyelesaian akan membentuk sebuah soludion space. Contoh penerapan algoritma searching dapat dilhat pada penentuan rute, navigasi robot, perencanaan pada block world, eight-queen problem pada catur,eight puzzle, dan berbagai macam contoh lainya[5].

\section{Metodologi Penelitian}

\subsection{Rancangan Penelitian}

Dengan digunakan metode kualitatif ini maka data yang didapatkan akan lebih lengkap, lebih mendalam, kredibel, dan bermakna, sehingga tujuan penelitian dapat dicapai[6].

\subsection{Instrumen Penelitian}

\subsubsection{Instrumen Pengumpulan Data}

Instrumen dalam penelitian berbentuk observasi, wawancara dan studi literatur. Observasi yaitu sebuah pengamatan secara langsung terhadap tempat penelitian. Wawancara dengan menanyakan langsung terhadap subyek pengujian program yaitu dosen kebidanan dan mahasiswa kebidanan.Studi Literatur instrumen diperoleh dengan melakukan studi terhadap penelitian sebelumnya.

\subsubsection{Instrumen Analisis Data \\ 3.2.2.1 Alat}

Alat yang digunakan antara lain: Personal komputer / PC, Sistem operasi Microsoft Windows 7 Ultimate, Eclipse Helios win 32,ADT 8.0.1, Android SDK, Java development kit 7 , Java MIDP Emulator dan handphone yang berbasis android.

\subsubsection{Bahan}

Bahan yang digunakan dalam penelitian yaitu Kamus Saku Kebidanan" Denise Tiran dan "Kamus Istilah Kebidanan"

\subsubsection{Instrumen Pengujian Data}

Sebelum instrumen digunakan digunakan sebagai pengumpulan data, maka instrumen penelitian harus di uji untuk mengukur kemampuan sebuah sistem dan sejauh mana sebuah sistem tersebut dapat di percaya.Penelitian Proses pengujian sistem dengan menaruh program yang berbentuk apk ke HP Samsung V SMG31HZ kepada dosen dan mahasiswa kebidanan dimana dosen dan mahasiswa kebidanan mendapat kemudahan dalam mencari arti atas istilah kebidanan.

\subsection{Teknik Pengumpulan Data}

Untuk mendapatkan kelengkapan informasi yang sesuai dengan fokus penelitian maka yang dijadikan teknik pengumpulan data adalah sebagai berikut :

\section{Teknik Observasi}

Observasi adalah pengamatan yang dilakukan secara sengaja, sistematis, mengenai fenomena sosial dengan gejala-gejala psikis untuk kemudian dilakukan pencatatan.Teknik ini dilakukan untuk mengetahui penggunaan kamus kebidanan dan ketersediaan kamus kebidanan di Perpustakaan Stikes Nurul Jadid.

2. Studi Literatur

Pada penelitian ini diperlukan suatu studi literatur terhadap penilitian penelitian sebelumnnya tentang : "Implementasi Algoritma Boyer-Moore pada Aplikasi Kamus Kedokteran Berbasis Android", "Aplikasi Kamus Online Bahasa Arab Indonesia" dan "Perancangan Aplikasi Kamus Bahasa Indonesia Karo Online Berbasis Web Dengan Metode Sequential Search". Hal ini perlu dilakukan untuk mendapatkan sebuah metode - metode atau perhitungan yang tepat sehingga menghasilkan sebuah aplikasi baik dan benar.

\subsection{Teknik Analisis Data}

Analisis data adalah proses mencari dan menyusun secara sistematis data yang diperoleh dari hasil wawancara, catatan lapangan, dan dokumentasi, dengan cara mengorganisasikan data ke dalam kategori, menjabarkan ke dalam unit-unit, melakukan sintesa, menyusun ke dalam pola, memilih mana yang penting dan yang akan dipelajari, dan membuat kesimpulan sehingga mudah dipahami oleh diri sendiri dan orang lain [7].

\subsection{Metode Pengembangan Sistem}

Metode pengembangan sistem yang digunakan penelitian ini menggunakan metode waterfall. Waterfall atau Classic Life Cycle Model. Model Waterfall ini merupakan model klasik yang bersifat sistematis, berurutan dalam membangun perangkat lunak. Pada model ini menyarankan pendekatan yang sistematis dan sekuensial dalam pengembangan perangkat lunak yang dimulai pada level sistem dan bergerak maju mulai tahap analisis, desain, coding, testing, operation, dan maintenance. Model Waterfall yang digunakan dalam membuat aplikasi adalah jenis Model Waterfall menurut referensi Sommerville [8].

\section{Hasil dan Pembahasan}

\subsection{Analisis Sistem}

Langkah - lagkah yang ditempuh yang berguna untuk mengetahui berbagai masalah yang ada, sehingga dengan adanya kamus kebidanan berbasis android ini diharapkan bisa membantu mahasiswa 
kebidanan dalam melakukan pencarian istilah kebidanan.

Adapun beberapa masalah tersebut adalah sebagai berikut :

1. Ketiadaan kamus kebidanan berbasis android yang bisa berjalan secara offline.

2. Proses pencarian yang masih menggunakan cara manual, masih membuka perlembar dari kamus istilah kebidanan.

3. Kamus secara manual tidak bisa mengikuti perkembangan ilmu kebidanan pada saat ini.

4. Adanya ketergantungan manusia terhadap teknologi.

Untuk mengatasi masalah ini diperlukan desain sebuah sistem terkomputerisasi untuk menggantikan cara manual yang selama ini masih digunakan oleh pengguna sehingga tingkat efisiensi dan efektifitas dalam mencari arti dari kamus istilah kebidanan dapat ditingkatkan. Mahasiswa kebidanan cukup memasukkan kata, maka secara otomatis akan ada tawaran kata dan arti kata yang akan ditampilkan secara listview pada layar.

\subsection{Desain Sistem}

Desain sistem adalah desain aplikasi kamus kebidanan berbasis android yang kemudian melakukan perancangan sistem model dengan menggunakan flowchart. Flowchart ini akan menunjukan alur kerja dari aplikasi kamus kebidanan. Maka untuk mendapatkan gambaran yang lebih jelas tentang bagian alir sistem aplikasi ini akan dilihat dari sistem Flowchart manual dan terkomputerisasi.

\subsubsection{Sistem FlowChart manual}

Di dalam analisis sistem akan dilihat dari suatu flowchart yang belum terkomputerisasi dan belum menggunakan data komputer di dalamnya maka, hasilnya adalah sebagai berikut :

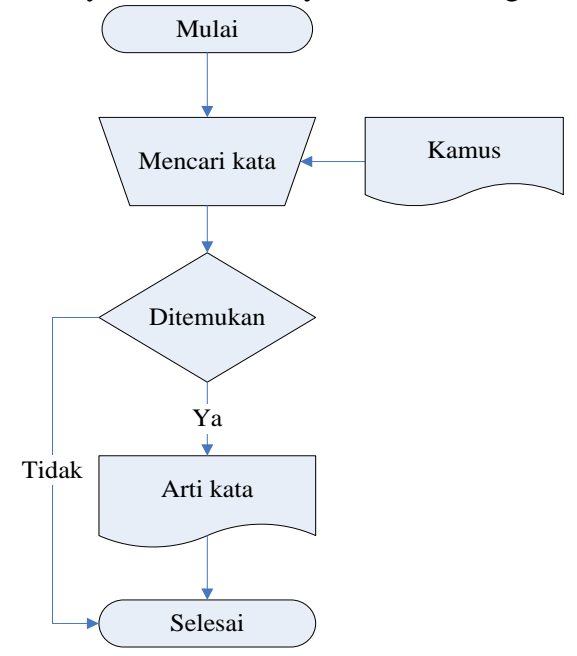

Gambar 1 Flowchart manual kamus kebidanan
Keterangan :

Mahasiswa kebidanan mencari kata dikamus istilah kebidan dari index, kata, kemudian arti kata, jika ditemukan maka akan ada arti kata dari kata yang dicari.

\subsubsection{Sistem FlowChart terkomputerisasi}

Di dalam analisis ini akan dilihat dari suatu flowchart yang sudah terkomputerisasi dan menggunakan database sebagai tempat penyimpanan data, hasilnya adalah sebagai berikut:

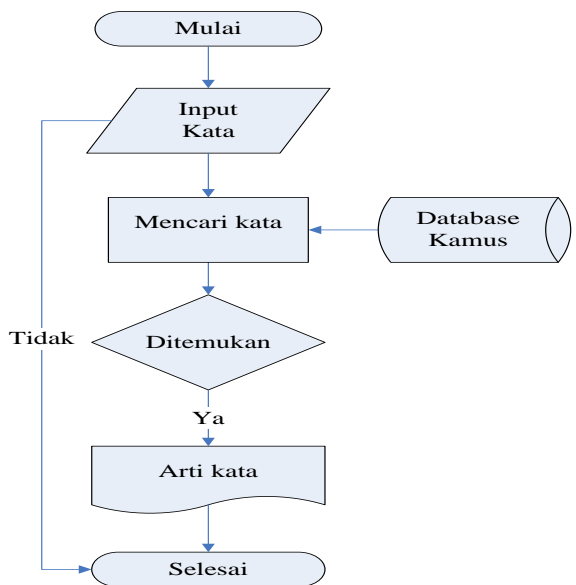

Gambar 2 Flowchart manual kamus kebidanan

Keterangan :

Mahasiswa kebidanan memasukkan kata pada sistem, kemudian sistem mencari kata di database, jika ditemukan maka akan muncul arti dari kata yang dicari.

\subsection{Implementasi Sistem 4.3.1 Tampilan Interface}

a. Tampilan Halaman Pencarian

Halaman selanjutnya adalah halaman pencarian, dimana saat mahasiswa kebidanan memilih tombol 'masuk', maka akan langsung mengarah ke dalam halaman ini. Di dalam halaman pencarian ini terdapat form inputan kata. Berikut ini adalah tampilan halaman pencarian :

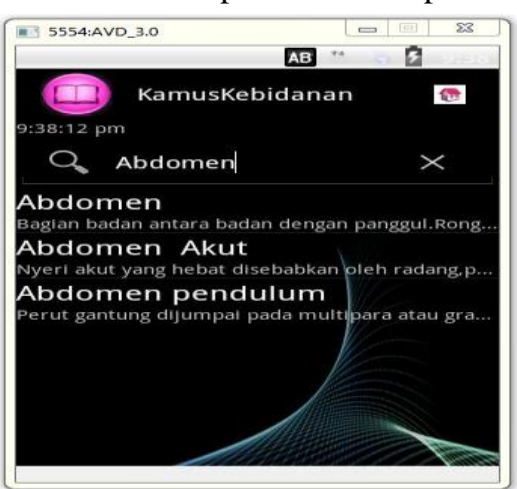

Gambar 3 Tampilan Halaman Pencarian 
Keterangan :

Pada halaman ini aplikasi akan melakukan pencarian, dimana ketika mahasiswa kebidanan memasukkan kata 'abdomen', maka aplikasi akan menyuguhkan ke layar berbagai pilihan kata dari yang hampir benar sampai yang paling benar.

\section{b. Tampilan Hasil Pencarian}

Halaman ini menunjukan ketika pilih kata 'abdomen' maka aplikasi akan membukanya dan memerlihatkan isinya (arti kata).

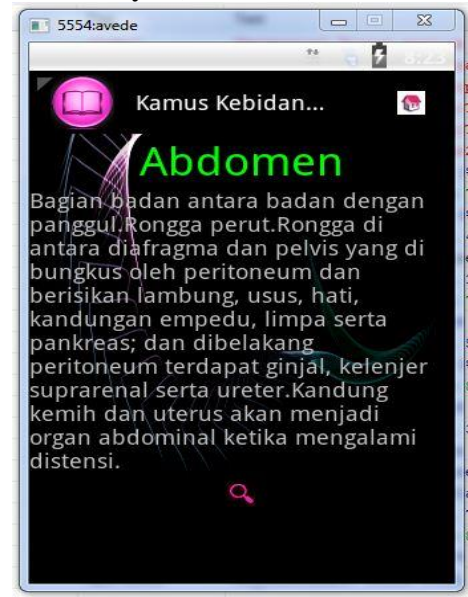

Gambar 4 Tampilan Hasil Pencarian

Keterangan :

Setelah mahasiswa kebidanan menemukan kata yang di cari maka aplikasi siap di pergunakan untuk pencarian kata selanjutnya dengan cara mengeklik gambar "Cari" pada aplikasi.

\section{Kesimpulan dan Saran \\ 5.1 Kesimpulan}

Kesimpulan yang dapat diambil dari ini adalah sebagai berikut :

1. Telah menghasilkan aplikasi kamus kebidanan berbasis android yang dapat memudahkan masyarkat dan mahasiswa kebidanan dalam mencari istilah yang ada dalam ilmu kebidanan.

\subsection{Saran}

Untuk pengembangan aplikasi ini kedepannya, berikut beberapa hal yang dapat disarankan :

1. Menambahkan lebih dari 2 buku kamus kebidanan sebagai rujukan dalam penambahan kata kebidanan.

2. Menambahkan fitur pencarian seperti voice search pada aplikasi ini sehingga proses pencarian kata kebidanan bisa lewat suara.
Daftar Pustaka:

[1] Adi Nugroho. 2005. Analisis dan Perancangan Sistem Informasi Dengan Metodologi Berorientasi Objek. Informatika. Bandung

[2] Tim Penyusun Kamus Pusat Pembinaan dan Pengembangan Bahasa (1989),Kamus Besar Bahasa Indonesia edisi kedua, Balai Pustaka.

[3] PERMENKES No.1464/MENKES/PER/X/2010

[4] Nazaruddin Safaat Harahap. 2012. Pemograman Aplikasi Mobile Smartphone dan Tablet PC Berbasis Android. Informatika. Bandung.

[5] Budiharto,Widodo dkk.2014.Artificial Inteligence Koonsep dan Penerapannya.Jakarta:CV Andi Offset.

[6] Moleong, Lexy J. (2007) Metodologi Penelitian Kualitatif,Penerbit PT Remaja Rosdakarya Offset, Bandung.

[7] Sugiyono (2010), Metode Penelitian Kuantitatif Kualitatif dan R\& D, Alfabeta Bandung.

[8] Umi Proboyekti. Software process model 1, http://www.Lecture.ukdw.ac.idm, 2008. 
SYSTEMIC

ISSN $\mathbf{2 4 6 0 - 8 0 9 2}$ 